\title{
Diterpenoids from the Roots of Salvia yunnanensis
}

\author{
Fan Xia $\cdot$ Chun-Yan Wu $\cdot$ Xing-Wei Yang $\cdot$ \\ Xian Li $\cdot$ Gang Xu
}

Received: 4 November 2015/ Accepted: 29 November 2015/Published online: 14 December 2015

(C) The Author(s) 2015. This article is published with open access at Springerlink.com

\begin{abstract}
Two new diterpenoids, salyunnanins I and J (1 and 2), together with ten analogues, were isolated from the roots of Salvia yunnanensis. The structures of the new isolates, possessing different neo-clerodane and seco-abietane diterpenoid skeletons respectively, were elucidated on the basis of comprehensive spectroscopic data. All of the compounds were tested for the inhibitory activities against six human tumor lines in vitro, and several ones showed moderate cytotoxic activities.
\end{abstract}

\section{Graphical Abstract}
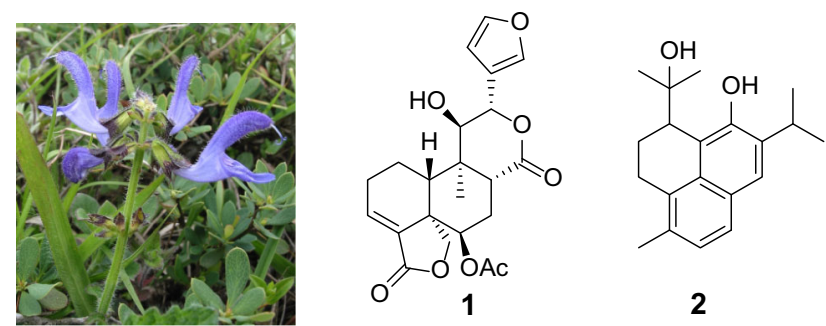

Keywords Salvia yunnanensis · Diterpenoid · Cytotoxicity

Fan Xia and Chun-Yan Wu have contributed equally to this work.

Electronic supplementary material The online version of this article (doi:10.1007/s13659-015-0080-4) contains supplementary material, which is available to authorized users.

\section{F. Xia $\cdot$ X. Li $(\bowtie)$}

School of Pharmaceutical Science and Yunnan Key Laboratory of Pharmacology of Natural Products, Kunming Medical University, Kunming 650500, People's Republic of China e-mail: xianlikm@163.com

\section{C.-Y. Wu · X.-W. Yang · G. Xu (ه)}

State Key Laboratory of Phytochemistry and Plant Resources in West China, Kunming Institute of Botany, Chinese Academy of Sciences, Kunming 650201, People's Republic of China e-mail: xugang008@mail.kib.ac.cn

\section{Introduction}

The genus of Salvia is a large pool of diterpenoids with structural diversity and biological properties [1-3]. Many diterpenoids with interesting bioactivities, such as tanshinone IIA, salvicine, neotanshinlactone, and salvinorin A, have been reported from this genus [4-6]. Salvia yunnanensis is a traditional Chinese herb used as the surrogate of $S$. miltiorrhiza (Danshen) for the treatment of various cardiovascular diseases [7]. Many bioactive abietane diterpenoids, especially a series of abietane type diterpene alkaloids, have been reported from this plant [8-10]. In a continuation of our research work on the diterpenoids from Salvia species, we examined the constituents of $S$. yunnanensis collected in 
Juhuacun traditional medicine market in the Yunnan province. As a result, two new diterpenoids, salyunnanins I and $\mathbf{J}(\mathbf{1}$ and $\mathbf{2})$, together with ten known analogues (3-12), were isolated (Fig. 1). It's noteworthy that the structures of the new isolates were elucidated to possess neo-clerodane and seco-abietane diterpenoid skeletons respectively. All of the compounds were tested for the inhibitory activities against six human tumor lines in vitro, and several ones showed moderate cytotoxic activities. Herein, we report the isolation, structural elucidation, and the biological evaluation of all the obtained isolates.

\section{Results and Discussion}

The acetone extract of the roots of S. yunnanensis was subjected to silica gel column chromatography eluting with petroleum ether-EtOAc to obtain seven fractions (I-VII), which were further purified by silica gel, Sephadex LH-20, and HPLC to afford two new diterpenoids (salyunnanins I and $\mathbf{J}, \mathbf{1}$ and 2) and ten known analogues: normiltioane (3) [11]; 5,6,7,8-tetrahydro-2,8,8-trimethyl-3-phenanthrenol (4) [12]; 6 $\alpha$-hydroxysugiol (5) [13]; sugiol (6) [14] 6-oxoferruginol (7) [15]; danshenxinkun B (8) [16]; tanshinone I (9) [17]; methyltanshinonate (10) [18]; tanshinone IIA (11) [19] and crypotanshinone (12) [20].

Salyunnanin I (1) was obtained as white powder. Its molecular formula $\mathrm{C}_{22} \mathrm{H}_{24} \mathrm{O}_{8}$ was established by its ${ }^{13} \mathrm{C}$ NMR and HR-EIMS data $\left([\mathrm{M}]^{+} m / z \quad 416.1467\right.$, calcd
416.1471). The IR spectrum exhibited absorption bonds due to hydroxyl $\left(3425 \mathrm{~cm}^{-1}\right)$ and lactone groups (1776 and $1747 \mathrm{~cm}^{-1}$ ). The ${ }^{13} \mathrm{C}$ NMR and DEPT spectroscopic data (Table 1) exhibited 22 carbon signals assignable to two methyls ( $\delta_{\mathrm{C}} 15.4$ and 21.0), four methylenes (including an oxygenated one at $\delta_{\mathrm{C}} 71.5$ ), nine methines (including four olefinic and three oxygenated ones at $\delta_{\mathrm{C}} 69.6,75.8$ and 78.4 ), and seven quaternary carbons (including two olefinic ones and three lactonic carbonyls at $\delta_{\mathrm{C}} 167.9,170.0$, and 173.5). Careful analysis of these ${ }^{13} \mathrm{C}$ NMR data indicated that the characteristic signals for a neo-clerodane diterpenoid of two quaternary carbons $\left(\delta_{\mathrm{C}} 49.9, \mathrm{C}-5 ; 40.7, \mathrm{C}-9\right)$, a methine $\left(\delta_{\mathrm{C}} 39.6, \mathrm{C}-10\right)$, an oxygenated methylene $\left(\delta_{\mathrm{C}}\right.$ $71.5, \mathrm{C}-19)$, and a substituted furan ring $\left(\delta_{\mathrm{C}} 125.5, \mathrm{C}-13\right.$; 109.8, C-14; 144.8, C-15; 141.1, C-16) were all presented. These evidence, conjugated with some same type of diterpenoid were previously isolated in our laboratory [21], suggested that compound $\mathbf{1}$ could be a neo-clerodane diterpenoid. The ${ }^{1} \mathrm{H}$ and ${ }^{13} \mathrm{C}$ NMR data (Table 1) of $\mathbf{1}$ were very similar to those of dugesin $\mathrm{E}$ [21], except that the methylene carbon at $\delta_{\mathrm{C}} 43.4(\mathrm{C}-11)$ in dugesin $\mathrm{E}$ was absent, while a down-field methine at $\delta_{\mathrm{C}} 75.8$ was instead present in $\mathbf{1}$. The difference implied that compound $\mathbf{1}$ was a C-11 oxygenated product of dugesin E. This assumption was supported by the HR-EIMS data, and further supported by the correlation from $\delta_{\mathrm{H}} 0.80(\mathrm{Me}-20)$ to $\delta_{\mathrm{C}} 75.8(\mathrm{C}-11)$ in the HMBC spectrum. Other partial planar structure of $\mathbf{1}$ was identical to those of dugesin $\mathrm{E}$ by detailed analysis of ${ }^{1} \mathrm{H}-{ }^{1} \mathrm{H}$ COSY and HMBC spectra (Fig. 2).
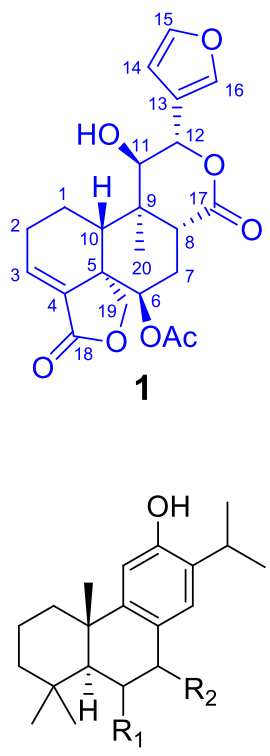

$$
\begin{array}{ll}
5 & \mathrm{R}_{1}=\alpha \mathrm{OH}, \mathrm{R}_{2}=\mathrm{O} \\
6 & \mathrm{R}_{1}=\mathrm{H}, \mathrm{R}_{2}=\mathrm{O} \\
7 & \mathrm{R}_{1}=\mathrm{O}, \mathrm{R}_{2}=\mathrm{H}
\end{array}
$$

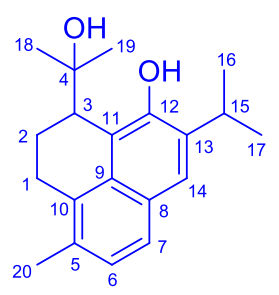

2<smiles>Cc1cccc2c3c(ccc12)C(=O)C(O)=C(C(C)C)C3=O</smiles>

8<smiles>CC1=CC2(O)CCC3C(C)(C)CCCC3(C)C2=CC1=O</smiles>

3<smiles>Cc1coc2c1C(=O)C(=O)c1c-2ccc2c(C)cccc12</smiles>

9<smiles>Cc1cc2ccc3c(c2cc1O)CCCC3(C)C</smiles>

4<smiles></smiles>

$10 \mathrm{R}=\mathrm{CO}_{2} \mathrm{Me}, \Delta{ }^{15,16}$

$11 \mathrm{R}=\mathrm{Me}, \Delta^{15,16}$

$12 \mathrm{R}=\mathrm{Me}$

Fig. 1 Structures of 1-12 isolated from Salvia yunnanensis 
Table $1{ }^{13} \mathrm{C}(125 \mathrm{MHz})$ NMR spectral data ( $\delta$ in ppm and $J$ in $\left.\mathrm{Hz}\right)$ of $\mathbf{1}$ and 2

\begin{tabular}{|c|c|c|c|c|}
\hline \multirow[t]{2}{*}{ No. } & \multicolumn{2}{|l|}{$\mathbf{1}^{\mathrm{a}}$} & \multicolumn{2}{|l|}{$2^{\mathrm{b}}$} \\
\hline & $\delta_{\mathrm{C}}$ type & $\delta_{\mathrm{H}}$, mult. & $\delta_{\mathrm{C}}$ type & $\delta_{\mathrm{H}}$, mult. \\
\hline \multirow[t]{2}{*}{1} & $20.9 \mathrm{CH}_{2}$ & 1.91, brd (12.8) & $23.4 \mathrm{CH}_{2}$ & $2.89, \mathrm{dd}(16.9,5.6)$ \\
\hline & & $1.28, \mathrm{~m}$ & & $2.77, \mathrm{~m}$ \\
\hline \multirow[t]{2}{*}{2} & $27.6 \mathrm{CH}_{2}$ & $2.32, \mathrm{~m}$ & $24.3 \mathrm{CH}_{2}$ & $2.33, \mathrm{~m}$ \\
\hline & & $2.23, \mathrm{~m}$ & & $1.92, \mathrm{~m}$ \\
\hline 3 & $139.9 \mathrm{CH}$ & $6.79, \mathrm{dd}(7.9,2.0)$ & $42.6 \mathrm{CH}$ & 3.50, brd $(5.8)$ \\
\hline 4 & $136.0 \mathrm{C}$ & & $78.9 \mathrm{C}$ & \\
\hline 5 & $49.9 \mathrm{C}$ & & $131.2 \mathrm{C}$ & \\
\hline 6 & $69.6 \mathrm{CH}$ & 5.24, brd (5.3) & $125.6 \mathrm{CH}$ & $7.09, \mathrm{~d}(8.3)$ \\
\hline \multirow[t]{2}{*}{7} & $24.8 \mathrm{CH}_{2}$ & $2.28, \mathrm{~m}$ & $125.4 \mathrm{CH}$ & $7.51, \mathrm{~d}(8.3)$ \\
\hline & & $2.10, \mathrm{~m}$ & & \\
\hline 8 & $39.0 \mathrm{CH}$ & $3.20, \mathrm{dd}(12.4,4.9)$ & $127.6 \mathrm{C}$ & \\
\hline 9 & $40.7 \mathrm{C}$ & & $129.7 \mathrm{C}$ & \\
\hline 10 & $39.6 \mathrm{CH}$ & $2.90, \mathrm{~m}$ & $129.9 \mathrm{C}$ & \\
\hline 11 & $75.8 \mathrm{CH}$ & $3.90, \mathrm{t}(6.2)$ & $117.3 \mathrm{C}$ & \\
\hline 12 & $78.4 \mathrm{CH}$ & $5.19, \mathrm{~d}(6.2)$ & $150.6 \mathrm{C}$ & \\
\hline 13 & $125.5 \mathrm{C}$ & & $137.6 \mathrm{C}$ & \\
\hline 14 & $109.8 \mathrm{CH}$ & 6.58, brs & $123.5 \mathrm{CH}$ & $7.49, \mathrm{~s}$ \\
\hline 15 & $144.8 \mathrm{CH}$ & 7.69, brs & $27.7 \mathrm{CH}$ & 3.45 , sept (6.8) \\
\hline 16 & $141.1 \mathrm{CH}$ & 7.60, brs & $23.1 \mathrm{CH}_{3}$ & $1.27, \mathrm{~d}(6.8)$ \\
\hline 17 & $173.5 \mathrm{C}$ & & $22.5 \mathrm{CH}_{3}$ & $1.35, \mathrm{~d}(6.8)$ \\
\hline 18 & $167.9 \mathrm{C}$ & & $29.6 \mathrm{CH}_{3}$ & $1.56, \mathrm{~s}$ \\
\hline \multirow[t]{2}{*}{19} & $71.5 \mathrm{CH}_{2}$ & $4.44, \mathrm{~d}(8.9)$ & $28.4 \mathrm{CH}_{3}$ & $0.93, \mathrm{~s}$ \\
\hline & & $4.18, \mathrm{~d}(8.9)$ & & \\
\hline 20 & $15.4 \mathrm{CH}_{3}$ & $0.80, \mathrm{~s}$ & $19.7 \mathrm{C}$ & $2.34, \mathrm{~s}$ \\
\hline$\underline{\text { COMe }}$ & $170.0 \mathrm{C}$ & & & \\
\hline $\mathrm{COMe}$ & $21.0 \mathrm{CH}_{3}$ & $1.99, \mathrm{~s}$ & & \\
\hline
\end{tabular}

${ }^{\text {a }}$ Recorded in acetone- $d_{6}$

b Recorded in $\mathrm{CDCl}_{3}$

In the NOESY spectrum, the NOE correlations of Me-20 with $\mathrm{H}_{2}-19$, of $\mathrm{H}-19 \mathrm{a}\left(\delta_{\mathrm{H}} 4.44\right)$ with $\mathrm{H}-6$, of $\mathrm{H}-10$ with $\mathrm{H}-8$, and of $\mathrm{H}-8$ with $\mathrm{H}-12$ indicated that the relative configurations of C-5, C-6, C-8, C-9, C-10, and C-12 of 1 were the same as dugesin $\mathrm{E}$. In addition, the strong $\mathrm{NOE}$ contact between Me-20 and H-11 defined the $\alpha$-orientation of H-11 (Fig. 2). Hence, the structure of 1 was elucidated and named salyunnanin $\mathrm{I}$.

Salyunnanin J (2) was assigned the molecular formula $\mathrm{C}_{20} \mathrm{H}_{26} \mathrm{O}_{2}$ by its ${ }^{13} \mathrm{C}$ NMR and HR-ESIMS $(\mathrm{m} / \mathrm{z} 321.1835$, $[\mathrm{M}+\mathrm{Na}]^{+}$) data, 18 mass units more than that of (3-rac)4,12-Epoxy-3,11-cyclo-4,5-seco-20(10 $\rightarrow$ 5)-abeo-abieta$5(10), 6,8,11,13$-pentaene, a cyclization product of aethiopionone [22]. Comparing of the NMR spectroscopic data of 2 (Table 1) with those of the cyclization product, about 14.7 and $1.7 \mathrm{ppm}$ up-field shifts for C-4 $\left(\delta_{\mathrm{C}} 78.9\right)$ and C-12 $\left(\delta_{\mathrm{C}} 150.6\right)$, respectively, were found in 2 , which indicated that $\mathbf{2}$ was a hydrolytic derivative of the known compound.
The HR-ESIMS data $\left(\mathrm{m} / \mathrm{z} 321.1835[\mathrm{M}+\mathrm{Na}]^{+}\right.$, calcd for 321.1830) supported this assumption. Furthermore, the correlations of $\mathrm{H}-1\left(\delta_{\mathrm{H}} 2.89,2.77\right) / \mathrm{H}-2\left(\delta_{\mathrm{H}} 2.33,1.92\right) / \mathrm{H}-3$ $\left(\delta_{\mathrm{H}} 3.50\right)$ and $\mathrm{H}-6\left(\delta_{\mathrm{H}} 7.09\right) / \mathrm{H}-7\left(\delta_{\mathrm{H}} 7.51\right)$ in the ${ }^{1} \mathrm{H}-{ }^{1} \mathrm{H}$ COSY spectrum, together with the correlations from $\mathrm{H}-1$ to C-5 $\left(\delta_{\mathrm{C}} 131.2\right)$ and C-9 $\left(\delta_{\mathrm{C}} 129.7\right)$, from H-3 to C-9, C-11 $\left(\delta_{\mathrm{C}} 117.3\right)$, and $\mathrm{C}-12\left(\delta_{\mathrm{C}} 150.6\right)$, from $\mathrm{H}-15\left(\delta_{\mathrm{H}} 3.45\right)$ to $\mathrm{C}-12, \mathrm{C}-13\left(\delta_{\mathrm{C}} 137.6\right)$, and C-14 $\left(\delta_{\mathrm{C}} 123.5\right)$, and from Me$20\left(\delta_{\mathrm{H}} 2.34\right)$ to $\mathrm{C}-5, \mathrm{C}-6\left(\delta_{\mathrm{C}} 125.6\right)$, and C-10 $\left(\delta_{\mathrm{C}} 129.9\right)$ in the HMBC spectrum further confirmed the structure of $\mathbf{2}$ (Fig. 3).

Salvia (including 700-1050 species) is the biggest genus in the medicinal important Labiatae family and widely distributed in the world [23, 24]. These plants are also a rich source of various diterpenoids, especially the clerodane and abietane diterpenoids with diverse skeletons. Structurally, the clerodane diterpeoids are typical bicyclic diterpenoids, while abietane are tricyclic diterpenoids. 


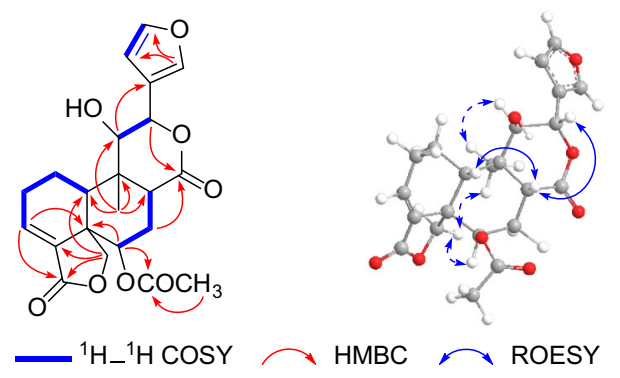

Fig. 2 Key HMBC, ${ }^{1} \mathrm{H}-{ }^{1} \mathrm{H}$ COSY, and NOESY correlations of $\mathbf{1}$

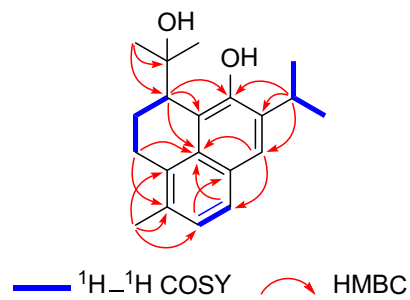

Fig. 3 Key HMBC and ${ }^{1} \mathrm{H}-{ }^{1} \mathrm{H}$ COSY correlations of $\mathbf{2}$

Accordingly, their biogenetic pathways are totally different with each other. Detailed investigation of the literatures revealed an interesting relationship between the diterpenoids constituents and its taxonomy of Salvia plants: the clerodane diterpenoids are usually reported from plants distributed in America, while abietane and related diterpenoids are commonly reported from plants in Asia. Up to now, these two types of diterpenoids have only been reported from a few Salvia plants, such as S. cardiophylia and $S$. lavanduloides, simultaneously [25, 26].

All of the compounds were tested for their cytotoxic effects against six human cancer cell lines (Hela, NCIH460, PC3, KB-3-1, MCF-7, and K562) using a previously described MTT method [27]. As shown in Table 2, compounds 5, 6, and 11 exhibited moderate activities.

In conclusion, totally twelve diterpenoids, including two new ones (salyunnanins I and J), were characterized from S. yunnanensis in this study. Eleven of the isolates were abietane diterpenoids, while salyunnanin I (1) was elucidated to be a neo-clerodane diterpenoid. In the bioassay of these isolates, several compounds exhibited moderate cytotoxic activities.

\section{Experimental}

\subsection{General Experimental Procedures}

Optical rotations were measured on a Jasco P-1020 polarimeter. UV spectra were detected on a Shimadzu UV2401PC spectrometer. IR spectra were determined on a
Table 2 Cytotoxcities of the isolates on six cancer cell lines with $\mathrm{IC}_{50}$ values $(\mu \mathrm{M})$

\begin{tabular}{lllllll}
\hline Compound $^{\text {a }}$ & HeLa & KB-3-1 & NCI-H 460 & PC3 & MCF-7 & K562 \\
\hline $\mathbf{5}$ & 7.7 & 7.7 & 7.4 & 6.0 & 8.7 & 5.0 \\
$\mathbf{6}$ & 10.9 & 9.1 & 8.9 & 10.5 & 11.4 & 6.7 \\
$\mathbf{7}$ & $>20$ & $>20$ & 17.2 & $>20$ & $>20$ & 15.9 \\
$\mathbf{9}$ & 16.7 & 12.8 & $>20$ & 5.2 & $>20$ & 6.1 \\
$\mathbf{1 1}$ & 10.1 & 9.2 & $>20$ & 8.9 & $>20$ & 5.5 \\
$\mathbf{1 2}$ & 17.1 & 10.3 & $>20$ & $>20$ & $>20$ & 13.6 \\
Paclitaxel $^{\mathrm{b}}$ & 0.01 & 0.003 & 0.004 & 0.007 & 0.21 & 0.005 \\
\hline
\end{tabular}

a Other selected ones not listed in the table were inactive $\left(\mathrm{IC}_{50}>20 \mu \mathrm{M}\right)$ for all cell lines

${ }^{b}$ Paclitaxel was used as positive controls

Bruker FT-IR Tensor-27 infrared spectrophotometer with $\mathrm{KBr}$ disks. 1D and 2D NMR spectra were recorded on DRX-500 spectrometers using TMS as an internal standard. Unless otherwise specified, chemical shifts $(\delta)$ were expressed in $\mathrm{ppm}$ with reference to the solvent signals. ESIMS and HR-EIMS analysis were carried out on Waters Xevo TQS and Waters AutoSpec Premier P776 mass spectrometers, respectively. Semi-preparative HPLC was performed on an Agile 1100 HPLC with a Zorbax SB-C 18 $(9.4 \times 250 \mathrm{~mm})$ column. Silica gel (100-200 and 200-300 mesh, Qingdao Marine Chemical Co., Ltd., PR China), and Amphichroic RP-18 gel (40-63 $\mu \mathrm{m}$, Merck, Darmstadt, Germany) and MCI gel (75-150 $\mu \mathrm{m}$, Mitsubishi Chemical Corporation, Tokyo, Japan) were used for column chromatography.

\subsection{Plant Material}

The roots of S. yunnanensis were collected in Kunming, Yunnan Province, PR China, in October 2010. The plant was identified by Dr. En-De Liu, Kunming Institute of Botany, Kunming, PR China. A voucher specimen was deposited at the Kunming Institute of Botany with identification number 201010S01.

\subsection{Extraction and Isolation}

The air-dried powdered material $(20 \mathrm{~kg})$ was extracted with acetone $(3 \times 50 \mathrm{~L} \times 24 \mathrm{~h})$ at room temperature and the solution was evaporated in vacuum to give a crude extract $(1.2 \mathrm{~kg})$. The extract was subjected to column chromatography over silica gel, eluting with $\mathrm{CHCl}_{3}-$ EtOAc to afford seven fractions (I-VII). Fraction II (311 g) was further chromatographed on silica gel (eluting with a gradient of EtOAc in petroleum ether) to yield seven subfractions (A-G). Subfraction B (54 g) was separated over an MCI-gel column ( $\mathrm{MeOH}-\mathrm{H}_{2} \mathrm{O}$ from 3:2 to 10:0) to obtain five fractions (Fr. B1-B5). Fr. B1 (12.5 g) was then 
chromatographed on a silica gel column eluted with petroleum ether-Chloroform (from 10:1 to 0:10), to yield four fractions (Fr. B1a-B1d). Fr. B1a (3.3 g) was repeatedly subjected to silica gel columns eluted with petroleum ether-EtOAc (from 500:1 to 2:1), and was then further purified by semi-preparative HPLC $\left(\mathrm{MeOH}-\mathrm{H}_{2} \mathrm{O}, 85: 15\right)$ to afford compounds 1 (6 mg) and $\mathbf{8}(4 \mathrm{mg})$. Fr. B2 (22 g) was isolated over an MCI gel column $\left(\mathrm{MeOH}-\mathrm{H}_{2} \mathrm{O}\right.$ from 75:25 to 100:0) to provide $2(15 \mathrm{mg})$ and $\mathbf{3}(3 \mathrm{mg})$. Similarly, compounds $4(35 \mathrm{mg}), 5(10 \mathrm{mg}), \mathbf{6}(18 \mathrm{mg})$, and 7 $(10 \mathrm{mg})$ from subfraction $\mathrm{C}(32 \mathrm{~g})$, and $\mathbf{9}(5 \mathrm{mg}), \mathbf{1 0}(430$ $\mathrm{mg}), \mathbf{1 1}(12 \mathrm{~g}), \mathbf{1 2}(5 \mathrm{~g})$ from subfraction D $(120 \mathrm{~g})$ were obtained.

\subsection{Cytotoxicity Assays}

The following human tumor cell lines were used: HeLa, NCI-H460, PC3, KB-3-1, MCF-7, and K562, which were kindly provided by Prof. David WF Fong of Hong Kong Baptist University. All cells were cultured in RPMI-1640 or DMEM medium [Gibco, Invitrogen (Shanghai), China] supplemented with $10 \%$ fetal bovine serum [Gibco, Invitrogen (NY), USA] at $37{ }^{\circ} \mathrm{C}$ in a humidified atmosphere with $5 \% \mathrm{CO}_{2}$. Cell viability was assessed by conducting colorimetric measurements of the amount of insoluble formazan formed in living cells based on the reduction of 3-(4,5-dimethylthiazol-2-yl)-2,5-diphenyltetrazolium bromide (MTT) (Sigma, St. Louis, MO, USA) [28]. Briefly, $100 \mu \mathrm{L}$ of adherent cells (HeLa, NCI-H460, PC3, KB-3-1, MCF-7) was seeded into each well of a 96-well cell culture plate and allowed to adhere for $24 \mathrm{~h}$ before test compound addition, while suspended cells (K562) were seeded just before test compound addition, both with an initial density of $1 \times 10^{5}$ cells $/ \mathrm{mL}$ in $100 \mu \mathrm{L}$ of medium. Each tumor cell line was exposed to the test compound at various concentrations in triplicate for $48 \mathrm{~h}$, with paclitaxel (Sigma) as positive control. After the incubation, $10 \mu \mathrm{L}$ of MTT ( $5 \mathrm{mg} / \mathrm{mL}$ in PBS) was added to each well, and the incubation continued for $4 \mathrm{~h}$ at $37^{\circ} \mathrm{C}$. After removing the medium, $100 \mu \mathrm{L}$ per well of DMSO was added to dissolve the residue and the optical density was measured at $492 \mathrm{~nm}$ in a 96-well microtiter plate reader (Bio-Rad 680). The $\mathrm{IC}_{50}$ value of each compound was calculated by Reed and Muench's method [27].

\subsubsection{Salyunnanin $J(\mathbf{1})$}

White powder; $[\alpha]_{\mathrm{D}}^{21}-95.7(c 0.22, \mathrm{MeOH}) ; \mathrm{UV}(\mathrm{MeOH})$ $\lambda_{\max }(\log \varepsilon): 208$ (4.10), 249 (3.24) nm; IR (KBr) $v_{\max }$ $3425,1776,1747,1374,1241,1189,1169,1024$, $1003 \mathrm{~cm}^{-1}$; ${ }^{1} \mathrm{H}$ and ${ }^{13} \mathrm{C}$ NMR data, see Table 1; negative ESIMS $m / z 451[\mathrm{M}+\mathrm{Cl}]^{-}$; HR-EIMS $m / z 416.1467[\mathrm{M}]^{+}$ (calcd for $\mathrm{C}_{22} \mathrm{H}_{24} \mathrm{O}_{8}, 416.1471$ ).

\subsubsection{Salyunnanin $K(\mathbf{2})$}

Yellow powder; $[\alpha]_{\mathrm{D}}^{16}-12.6(c 0.10, \mathrm{MeOH}) ; \mathrm{UV}(\mathrm{MeOH})$ $\lambda_{\max }(\log \varepsilon): 195$ (4.22), 237 (4.69), 288 (3.68), 332 (3.36) $\mathrm{nm}$; IR (KBr) $v_{\max } 3431,2963,2923,2855,1626,1461$, 1417, 1249, $1231 \mathrm{~cm}^{-1} ;{ }^{1} \mathrm{H}$ and ${ }^{13} \mathrm{C}$ NMR data, see Table 1; EIMS $m / z, 298$ [M] $^{+}$; HR-ESIMS $m / z, 321.1835$

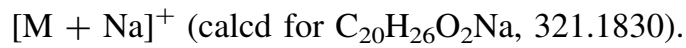

Acknowledgments The work was financially supported by the National Natural Sciences Foundation of China (81373291), the National Science and Technology Support Program of China (2013BAI11B02), and the foundation from Chinese Academy of Sciences to Dr G. Xu.

\section{Compliance with Ethical Standards}

Conflict of interest The authors declare no conflict of interest.

Open Access This article is distributed under the terms of the Creative Commons Attribution 4.0 International License (http:// creativecommons.org/licenses/by/4.0/), which permits unrestricted use, distribution, and reproduction in any medium, provided you give appropriate credit to the original author(s) and the source, provide a link to the Creative Commons license, and indicate if changes were made.

\section{References}

1. L. Rodriguez-Hahn, B. Esquivel, A.A. Sanchez, J. Cardenas, O.G. Tovar, M. Soriano-Garcia, A. Toscano, J. Org. Chem. 53, 3933-3936 (1988)

2. H.M. Chang, K.P. Cheng, T.F. Choang, H.F. Chow, K.Y. Chui, P.M. Hon, F.W.L. Tan, Y. Yang, Z.P. Zhong, J. Org. Chem. 55, 3537-3543 (1990)

3. Z.H. Pan, G. Xu, Q.S. Zhao, Guang Xi Zhi Wu 30, 781-790 (2010)

4. M. Xue, Y.B. Shi, Y. Chui, B. Zhang, Y.J. Luo, Z.T. Zhou, W.J. Xia, R.C. Zhao, H.Q. Wang, Nat. Prod. Res. Dev. 12, 27-32 (2000)

5. L.H. Meng, J.S. Zhang, J. Ding, J. Biochem. Pharm. 62, 733-741 (2001)

6. X.H. Wang, K.F. Bastow, C.M. Sun, Y.L. Lin, H.J. Yu, M.J. Don, T.S. Wu, S. Nakamura, K.H. Lee, J. Med. Chem. 47, 5816-5819 (2004)

7. Kunming Institute of Botany, Chinese Academy of Sciences, Flora Yunnannica, vol. 1 (Science Press, Beijing, 1997), pp. $656-689$

8. M.J. Don, C.C. Shen, Y.L. Lin, W.J. Syu, Y.H. Ding, C.M. Sun, J. Nat. Prod. 68, 1066-1070 (2005)

9. F.W. Lin, A.G. Damu, T.S. Wu, J. Nat. Prod. 69, 93-96 (2006)

10. G. Xu, L.Y. Peng, L. Lu, Z.Y. Weng, Y. Zhao, X.L. Li, Q.S. Zhao, H.D. Sun, Planta Med. 72, 84-86 (2006)

11. D.W. Zhang, X. Liu, D. Xie, R. Chen, X.Y. Tao, J.H. Zou, J. Dai, Chem. Pharm. Bull. 61, 576-580 (2013)

12. H.M. Chang, K.Y. Chui, F.W.L. Tan, Y. Yang, Z.P. Zhong, C.M. Lee, H.L. Sham, H.N.C. Wong, J. Med. Chem. 34, 1675-1692 (1991)

13. C.F. Chyu, Y.M. Chiang, H.C. Lin, Y.H. Kuo, Tetrahedron Lett. 45, 641-643 (2004)

14. E. Wenkert, J. De Paiva Campillo, J.D. McChesney, D.J. Watts, Phytochemistry 13, 2545-2549 (1974) 
15. Y.H. Kuo, M.T. Yu, J. Nat. Prod. 60, 648-650 (1997)

16. G. Nagy, G. Gunther, I. Mathe, G. Blunden, M.H. Yang, T.A. Crabb, Phytochemistry 52, 1105-1109 (1999)

17. Y.R. Shi, N. Zaesung, H.K. Sung, W.A. Jong, Planta Med. 63, 44-46 (1997)

18. H. Kakisawa, T. Hayashi, I. Okazaki, M. Ohashi, Tetrahedron Lett. 28, 3231-3234 (1968)

19. W.S. Chen, X.M. Jia, W.D. Zhang, Z.Y. Lou, C.Z. Qiao, Acta Pharm. Sin. 5, 354-357 (2003)

20. A.G. Gonzalez, Z.E. Aguiar, T.A. Grillo, J.G. Luis, Phytochemistry 31, 1691-1695 (1992)

21. G. Xu, F. Zhao, X.W. Yang, J. Zhou, L.X. Yang, X.L. Shen, Y.J. $\mathrm{Hu}$, Q.S. Zhao, Nat. Prod. Bioprospect. 1, 81-86 (2011)

22. M.J. Sexmero Cuadrado, M.C. De la Torre, L.Z. Lin, G.A. Cordell, B. Rodriguez, A. Perales, J. Org. Chem. 57, 4722-4728 (1992)
23. Y.B. Wu, Z.Y. Ni, Q.W. Shi, M. Dong, H. Kiyota, Y.C. Gu, B. Cong, Chem. Rev. 112, 5967-6026 (2012)

24. Y.Z. Dong, S.L. Morris Natschke, K.H. Lee, Nat. Prod. Rep. 28, 529-542 (2011)

25. A.G. Gonzalez, J.R. Herrera, J.G. Luis, A.G. Ravelo, E.A. Ferro, Phytochemistry 27, 1540-1541 (1988)

26. E. Maldonard, M. De los Angeles Flores, B. Salazar, A. Ortega, Phytochemistry 37, 1480-1482 (1994)

27. M.C. Alley, D.A. Scudiero, A. Monks, M.L. Hursey, M.J. Czerwinski, D.L. Fine, B.J. Abbott, J.G. Mayo, R.H. Shoemaker, M.R. Boyd, Cancer Res. 48, 589-601 (1988)

28. A. Monks, D. Scudiero, P. Skehan, R. Shoemaker, K. Paull, D. Vistica, C. Hose, J. Langley, P. Cronise, A. Vaigro-Wolff, J. Nat. Cancer Inst. 83, 757-766 (1991) 